\title{
(息)
}

Citation:

Singh, D (2015) Explaining varieties of corruption in the Afghan justice sector. Journal of Intervention and Statebuilding, 9 (2). 231 - $255 . \quad$ ISSN 1750-2977 DOI: https://doi.org/10.1080/17502977.2015.1033093

Link to Leeds Beckett Repository record:

https://eprints.leedsbeckett.ac.uk/id/eprint/2646/

Document Version:

Article (Accepted Version)

The aim of the Leeds Beckett Repository is to provide open access to our research, as required by funder policies and permitted by publishers and copyright law.

The Leeds Beckett repository holds a wide range of publications, each of which has been checked for copyright and the relevant embargo period has been applied by the Research Services team.

We operate on a standard take-down policy. If you are the author or publisher of an output and you would like it removed from the repository, please contact us and we will investigate on a case-by-case basis.

Each thesis in the repository has been cleared where necessary by the author for third party copyright. If you would like a thesis to be removed from the repository or believe there is an issue with copyright, please contact us on openaccess@leedsbeckett.ac.uk and we will investigate on a case-by-case basis. 


\section{Explaining varieties of corruption in the Afghan Justice Sector}

\section{Danny Singh}

Judicial reform in Afghanistan is seriously undermined from systemic corruption that has resulted in low legitimacy of the state and weak rule of law. This article reviews the main shortcomings in the Afghan justice system with reference to 70 interviews conducted in Kabul. Building on legal pluralism and a political economy approach, the shortcomings and causes and consequences of corruption in the Afghan justice sector are highlighted. These range from low pay, resulting in bribery; criminal and political intrusion of the judiciary; non-adherence with meritocracy and poorly educated judges and prosecutors; and low funding in the judicial sector resulting in weak case tracking and human rights abuses in the countryside. This is followed by sociological approaches of understanding corruption from a non-Western approach and emphasis on religion, morality and ethics in order to curb it.

Keywords: Corruption; clientelism; judicial reform; Afghanistan; rule of law; narcotics; state capture; community-based dispute resolutions

\section{Introduction}

This article examines the main causes and practices of corruption and clientelism in the Afghan justice sector. It initially defines corruption in basic terms followed by an explanation of legal pluralism adopted in context of merging all facets of the Afghan judicial sector. It employs a political economy approach - that includes Afghan social contract - to assess corruption. The social contract concerns the perceived authority and legitimacy of the state and socially accepted and unaccepted behaviours of adjudicators. This is to analyse the bureaucratic structures and entry-points for corruption and the social norms that commence during transactions between adjudicators and citizens. The analysis reveals that there are many interpenetrating features of the causes and consequences of corruption in the judicial sector that also stretches beyond the formal bureaucratic structures of the state and its formal institutions. This is due to the engrained social processes, fragmented solidarity networks and malleable local power structures - tribal qawm systems - in place. Moreover, non-meritocratic appointments and poorly educated judges and prosecutors within the Afghan justice sector have led to a lowly skilled judiciary that is 
susceptible to corrupt practices. Due to the corrupt formal justice system, citizens prefer community-based dispute resolution processes headed by tribal elders and the Taliban that arguably breach fundamental human rights, particularly against young girls and women.

Subsequently, sociological lenses of studying corruption are analysed. This includes a functionalist approach which reveals that bribery greases the wheels of rigid bureaucratic machinery. However, this paper argues that corruption has actually weakened the social contract and faith in the judicial sector. The paper then goes on to argue that corruption is socially constructed and thus cultural understandings and manifestations of corruption are of importance. Religion, morality and ethics have a role to play on developing an understanding of corruption and efforts to curb it by including local power-holders.

\section{Research Methodology}

70 semi-structured interviews of approximately 60-90 minutes were conducted predominantly in Kabul during the months May-June in 2010 and 2012 respectively. Permission to utilize verbatim tape-recorded transcripts was granted by all participants. These were conducted with elites of non-governmental organizations (NGOs), ministries, international organizations, civil society groups and students. Questions were centred on efficiency, effectiveness and accessibility of judicial, dispute resolution, anti-corruption and public services. This paper reflects on responses, as the empirical base, on judicial reform and the manifestations, causes and consequences of judicial corruption, human rights violations and additional shortcomings. Academic literature and civil society perception reports are consulted for triangulation purposes. The analysis utilizes various approaches on corruption. These include legal pluralism, political economy and sociological perspectives.

\section{Defining Corruption}

There are many contested definitions of corruption. Within a legal framework, corruption entails the abuse of public office or resources within a public role for private gain. This definition has been prescribed by international anti-corruption bodies such as Transparency International and the World Bank (Boucher et al. 2007). Corruption here is defined as an illegal 'economic activity involving the receipt of financial or material resources by parties concerned' (Rimsky 2005, 32). Corruption more generally is often associated with bribery, extortion and other forms of administrative abuses of power and authority for personal gain beyond monetary interests.

A broader definition of corruption is provided by Nye $(1967,417)$, who identified corruption 
as 'behaviour that deviates from the formal duties of a public role (elective or appointive) because of private-regarding (personal, close family, private clique) wealth or status gains'. The private gains and payoffs are part of social corruption. Clientelism is also linked to nepotism, ethnic and tribal favouritism. Applying a broad notion of corruption may span beyond giftgiving/tipping, minor gratuities and include other actions that are not deemed moral such as 'womanizing' and lying in certain cultures (Pavarala and Malik 2010, 20). In Afghan culture, the term fasad means something or an action viewed as 'dirty or prostitute' which cannot be supported (De Lauri 2013, 534). Gupta (1995) reveals that many definitions of corruption are culturally biased and ignore the cultural connotations as to what subjectively qualifies as corruption. Corruption is socially constructed in all societies with some activities blatantly qualifying as corruption but in other societies such action(s) may be an accepted part of preserving social relations.

\section{Analytical Approaches}

Now that the narrow and broad definitions of corruption have been addressed, theoretical frameworks to analyse corruption will follow. These theoretical frameworks to assess corruption include legal pluralist, functionalist and political economy approaches. The main body of the paper will examine shortcomings and corruption in the Afghan judicial system which will reflect on the theoretical frameworks. The subsequent section will cover sociological approaches to corruption that also includes an emphasis on morality, ethics and religion.

\section{Legal Pluralism}

Legal pluralism concerns multiple legal systems within a society or political unit. Structures of dispute resolution and customary norms and law exist alongside formalized and dominant laws within a constitutional regime either imposed by a former colony or international intervention (Pimentel 2011, 59). Usually, these structures cover land, family and marriage issues but other issues such as criminal cases and transactions overlap in informal and formal justice sectors. The mode of legal claim/dispute resolution depends on best interests, advantage and accessibility. The customary methods of dispute resolution will usually be mentioned in national constitutions as evident in the context of Afghanistan's 2004 Constitution. After the forcible removal of the Taliban, Afghanistan's assembly of stakeholders - a so-called Loya Jirga - passed the 2004 Constitution. An attempt has been made to juggle local codes of dispute resolution, codified and 
uncodified Shari'a law and secular law. Articles 3, 6 and 7 of the 2004 Afghan Constitution state that a sustainable justice system should respect Islamic legal tradition and remain open to interpreting older Islamic jurisprudence in compliance with human rights and public accountability (Tondini 2007, 334). This coexists and contests local and informal modes of legal practice.

There were numerous projects in Afghanistan that attempted to reconcile state justice exercising the rule of law and fundamental human rights such as the right to a defence lawyer and fair trial with Jirgas ${ }^{1}$. Wimpelmann (2013) cites the Department for International Development (DFID) Justice Adviser: United Kingdom (UK) Aid efforts of building the capacity and competence, including training, of formalized legal rules and the rule of law in southern Afghanistan. The Justice Adviser claimed that DFID was working on enhancing informal means of redress mainly in Helmand. This was 'to build accountability from the bottom-up process within local councils so that there can be accountability at both levels to rebuild faith in the formal legalized rules and standards across Afghanistan'?

Legal pluralism has thus partly been adopted in Afghanistan to merge several codes of legal and customary practices that adhere with the rule of law and human rights standards. However, this approach has predominantly been top-driven and the judicial sector has received minor funding compared with the security forces. It is debatable as to whether Afghans trust the formal justice system, but they may also not agree to the secular norms. Human rights issues are also contested, particularly with discrimination against women. For many, or even most, discriminating against women is not only acceptable, but desirable. Hence, Afghans may be taking cases to local courts precisely because, not despite, of human rights violations. In addition, case tracking mechanisms in the countryside are virtually non-existent. The following part will discuss these shortcomings.

\section{Low Funding in the Afghan Judicial Sector}

Italy was the lead donor overseeing Afghan judicial reform. Yet, Italy has failed to sufficiently invest in the judicial pillar. Only a meagre 2-4 per cent of the entire Security Sector Reform (SSR) budget was funded to the justice sector (World Bank 2005; Sedra 2006, 100; Tondini 2010, 61). 90 per cent of public expenditure was supplied by international assistance and a staggering USD $\$ 36$ billion a year is provided by the US military that primarily funds military and police reform (Waldman 2008, 1-3).

Philp's $(2008,324)$ assessment of corruption is pragmatic and recognizes that corruption alongside the rule of law and justice initially was clearly not a priority in Afghanistan. The 
Director of Integrity Watch Afghanistan (IWA) similarly stated that judicial reform "was not a priority of the international community until recently when they realized that the Taliban were gaining support and arguably legitimacy. The Taliban are making their laws and courts [which is in many areas] utilized more than the state formal justice system'. ${ }^{3}$ This perception is complicit of Taliban mobilization as recognized by international actors due to the lack of courthouses in the countryside. As a result, from 2008-10, the US poured funds into informal justice. The counter-insurgency reacted to public demand for justice where they were in power, allowing to get a foothold where they were not fully established. This was due to the failure of the first phases of SSR that failed to make an impact on the formal justice sector which remains weak, inaccessible and corrupt. This security problem led to support in the informal sector to deliver access to justice as part of stabilization attempts as 'Winning Hearts and Minds'.

\section{Corruption leading to informal means of redress}

Corruption and frustration with the Afghan justice system is widely noted. De Lauri (2013) identifies that the externally-driven centralized judicial system in Afghanistan has institutionalized corruption and alienated illiterate poor civilians ${ }^{4}$ from inaccessible court systems. Most Afghans revert to traditional justice due to long-delays, high costs, difficulty of understanding laws and lack of capacity and inadequacy of the state legal system which is prone to corruption and unable to deliver impartial justice (Wardak 2005, 62).

Many civil disputes (such as divorce, marriage, inheritance and domestic violence) and land issues are settled privately without involving state or provincial institutions. DFID's Justice Adviser stated that the majority of civil and minor criminal cases 'are best dealt with at the local level using means of resources used for centuries which also maintains peace and security at the community level'.5 The informal dispute sector promotes reconciliation, consensus and reintegration of criminal perpetrators into society in compliance with local customs. This process is facilitated by an elder, Mullah or even the Taliban to seek compromises and reconciliation from both parties, debatably fitting a model of restorative justice.

Wardak (2004) claims that around 80 per cent of Afghan citizens seek redress at the informal level - Jirga - rather than the court. Many of the interviewees shared the same notion and quoted the exact figure. ${ }^{6}$ DFID's Justice Adviser claimed that in Helmand over 99 per cent of disputes are 'solved in informal justice settings including the Taliban so there is no outreach of the justice system in remote areas so people have no access to it'. ${ }^{7}$ The Operations Officer of the World Bank's Afghanistan Reconstruction Trust Fund (ARTF) also stressed that 'the Taliban allegedly have a shadow government in many parts of the country where there is a governor and provincial 
departments of justice' ${ }^{8}$ Hence, according to the officials interviewed, customary law is spread outside of the capital and is accessible to the rural population - many are illiterate - that trust the reasoning of tribal elders or the Taliban in Jirgas. Jirgas are cost-effective and provide a fast means of dispute resolution. This is the case even if people are unsatisfied with communitybased dispute resolution processes. To provide one example, the Peacebuilding and Public Relations Manager of the Afghanistan Civil Society Forum organization (ACSFo) stated that

In Afghanistan, there is no justice because the formal system is too expensive for citizens and in the provinces there is no other option but traditional justice. I believe in codified equal rights before the law. Justice should not be based on traditional barbaric practices but at the moment there is no other option and some cases are very inhumane, brutal and against human rights. If you kill somebody by accident you have to give your sister as a sacrifice to the deceased's brother as a price. This is not good. If the Government does not provide justice then what should people do? At the moment, there is no other option. The judiciary in Afghanistan is too corrupt and no one has faith in it. ${ }^{9}$

These manifestations as provided by the interviewees provide an understanding of corruption and the reasons as to why people consult community-based resolution processes, largely due to inaccessibility of courthouses. Another debatable reason is due to prevalent corruption within the judiciary. These factors can be found in many policy reports such as the Centre for Policy and Human Development (2007, 9-11) and Afghanistan National Development Strategy (ANDS) (2008). The international approach to corruption consisted of reforming the justice sector in centralized zones. Subsequently, the approach attempted to replicate legal standards and the rule of law in the countryside (as part of legal pluralism). This has actually led to corruption and Taliban reactivity in southern areas of Afghanistan.

\section{Human Rights Violations against Women}

As part of the legal pluralist framework in Afghanistan, Shari'a Law has been included in the 2004 Afghan Constitution. In many provinces, including Helmand, the Taliban head community-based dispute resolutions. They procedurally breach human rights such as the right to a fair trial, the right to an appeal, and 'often dispense cruel, harsh and disproportionate corporal punishment' especially against women (Fearon 2010, 20). In Pashtun tribal codes of community-based dispute resolution (Pashtunwali), ba'ad - the practice of the perpetrator's family giving girls away for marriage to the victim's family - is prevalent. The idea is that an 
aggrieved party will have their honour restored by their ability to attain compensation. A Legal Researcher at the Max Planck Institute stressed that such practices, even though he was against it, are endorsed in order to settle a dispute such as murder or other insults to honour due to the instructions of a local council to promote reconciliation and avert a blood feud. ${ }^{10}$ The knowledge of $b a^{\prime} a d$ and the legal issues surrounding it are in compliance of an international approach to advocating human rights which is part of judicial reform strategy and more broadly legal pluralism. Handing over girls for compensation is punishable with up to two years imprisonment under the Afghan Criminal Code. $B a^{\prime}$ ad also breaches fundamental human rights but females in these circumstances are often reluctant to complain against the agreed actions of relatives. Moreover, the Executive Director of the Afghanistan Independent Bar Association (AIBA) claimed that the right to a trained defence lawyer is often not known and women are excluded from Jirgas. ${ }^{11}$ One could argue that the opinions of the interviewees are based on international approaches to human rights, gender rights and the strategy of legal pluralism by attempting to copy legal standards to community-based dispute resolution processes.

\section{Low Judicial Capacity and Failure of Case Tracking}

Judicial capacity is weak and this has resulted in shortcomings such as low numbers of judges to hear cases. A Human Rights Director of The Asia Foundation stated that 'in the formal justice sector there is not enough capacity, a lack of transparency and there is corruption which is the main problem which is definitely present in the Attorney General, Ministry of Justice and Supreme Court altogether'. ${ }^{12}$ At the national level, there are approximately 21,300 people to one judge; the ratio in Kandahar is 76,200 to one judge and 60,200 to one judge in Helmand (Röder and Zia 2010, 16). The Supreme Court does not have the capacity 'to detect, investigate and prosecute cases of judicial misconduct, especially outside' Kabul (Chêne 2007, 3). The Director of IWA argued that 'the biggest amount of corruption in the justice system happens at the district level then at the provincial and then at the national level with the Supreme Court and other bigger institutions but the core of it is really in the province and so it needs to be addressed.' ${ }^{13}$ However, these arguments suggesting that the lack of capacity and/or resources with corruption is conflated. It is debatable whether corruption is either a direct cause or consequence of the capacity problem.

Outcomes of cases are difficult to trace in the countryside. Reviewing cases and building up case law is virtually impossible. Centralized services fail to reach the majority of rural Afghans. There is no case tracking system at the provincial level which fails to monitor human rights at the Jirga level and state accountability remains limited. There is no official record-keeping 
system for decisions made in the informal systems which can lead to disputes re-emerging, particularly in land cases (Coburn and Dempsey 2010, 15) and corruption in the countryside. Yet, this may happen in cases based on secular law also. The Special Advisor to the Executive Director of International Assistance Mission (IAM) argued that 'the drain of resources is the problem' and provinces 'do not have enough resources for the judicial system or the process will drag out and it is also difficult to have a transparent scheduling system that issues a case, taking its time until it gets treated'. ${ }^{14}$ Lack of tracking systems lead to manipulation by judges who avoid using certain laws for their own interests. ${ }^{15}$ The Team Leader of Afghanistan Rule of Law Project (ARoLP) stressed that at the rural level many decisions are not written down and are unreported with the parties agreeing to a resolution without a record. ${ }^{16}$ These perceptions reveal that there is an emphasis on capacity concerns in the countryside. This delays proceedings which entices bribery and extortion. However, it should be acknowledged that courthouses in centralized parts of Afghanistan are arguably susceptible to corruption. Other factors include whether the plaintiff gets what they want during judicial processes - irrespective of locality and if the results are negative then the perception(s) will mirror it. Additional problems, namely concerning corruption, within the Afghan judicial system can be comprehended with a political economy lens.

\section{Political Economy Approach}

A political economy approach centres on the bureaucracy and behaviours of the state and actors. This includes coping mechanisms for lowly paid civil servants and law enforcement actors. Rose-Ackerman (1999) argues that a political economy approach is useful in analysing coping strategies that lead to survival-based corruption to supplement low incomes.

Although a political economy approach is useful for the study of what constitutes corruption in a certain society, its actors and wider public provide a starting point for analysis. North et al. (2013) underline that in less developed states governed by corrupt elites with 'limited access orders', the close interrelationship between political and economic power is formed by economic rents. Principal-agent relationships are formed by elite bargaining and the principal figure may be a corrupt elite. Subsequently, formal bureaucratic institutions including state institutions and regulatory agencies operate in accordance with this political arrangement. This includes the norms and incentives that control the behaviours of these political and economic actors. The elites from the top level such as a presidential cabinet have the authority to either centralize or disperse the accretion of rents. The economic mechanisms of rent-seeking entail the 
utilization of resources in order to own the recipient's surplus. For instance, a government may hire lobbyists to influence public policy and/or a contract to benefit their clients, such as a company or particular supporters, and undermine their competitors. This does not benefit the entire marketplace due to the nature of coerced trade, state resources and other economic benefits to one preferred side/group. Therefore, firms or illicit enterprises may attempt to influence elitist decisions when distributing or redistributing benefits such as income or state resources for private gain. Rent-seeking thus links with clientelism. As a consequence, 'in a marketplace where the state offers a certain right or preferential treatment [...] firms compete against each other in their demand of this' (Lambsdorff 2002, 101). This has political significance for the elite to bargain and on public decision-making. Rent-seeking can take various forms such as black market engagement and drug smuggling (Krueger 1974, 291).

Rent-seeking behaviour can be challenged by the provision of limitations on corrupt relationships at the institutional level. Moreover, actions from regulatory and anti-corruption agencies can also pose challenges. Competitiveness with open markets and widening of a private sector and the measurement of risks are other aspects that can combat and/or prevent corrupt relationships and rent-seeking behaviour. However, rent-seeking will persist if governments 'do not have incentives for restricting themselves' (Lambsdorff 2002, 98).

In patronage-based systems, elites may seek and utilize rents to benefit a group, tribe or ethnicity by distributing or redistributing resources and benefits which may hinder wider economic development. In such systems, informal rules govern politics while efforts from donors centralize and formalize legal requirements and enhance political competition in a contradictory process. By way of illustration, Bliesemann de Guevara and Kühn (2013) analysed how international statebuilding has resulted in a rentier Afghan state being built by donor and elite dealings. For instance, in Afghanistan enforcing human rights nationwide and anticorruption efforts do not serve the interests of the government. The Country Director of Global Rights stated that Karzai's cabinet and political cronies are not incentivized to conform with human rights and anti-corruption 'because it is not to their benefit'. ${ }^{17}$ Checks and balances are further needed, particularly when elites do not abide by rules. One could argue that the perception indicates that there are issues with the state governance that behaves to protect its interests and cronies. Moreover, the perception clearly supports an international approach to corruption, namely the association of numerous corruption probes against Karzai, his family and political aides. ${ }^{18}$

There are economic opportunities related to the size of the payoffs and avoidance of punishment. The government can purchase and sell assets, services and contracts and public 
officials usually have a wealth of information and are the face of providing basic services. This allows for corrupt activities ranging from requesting bribes for obtaining paperwork, licences and access to services. Moreover, clientelism within neo-patrimonial systems operates so that elites can maintain power, authority and political relations. Senior elites have the capacity to distribute state resources, economic benefits, jobs and favours to preserve loyalty. ${ }^{19}$ In a survey conducted by Transparency International's Centre for Media Studies (2005), the majority of citizens surveyed indicated that they had personally paid bribes or used a contact to proceed with a general service request to an administrative body.

These aforementioned issues can be analysed in the context of the Afghan justice sector. Chêne (2009) recognizes that it is widely debated that bribery and extortion are due to low pay and are part of 'individual coping strategies' as a means to supplement low income. State capture has become possible as main parts of the state - including the justice sector - have been permeated by political and criminal interests which hinder the rule of law, justice and anticorruption investigations. The Afghan social context has formed factional competition and clientelistic networks that have contributed to patronage, nepotism and unfair distribution of state resources and jobs. In spite of adjudicators lacking educational qualifications, awareness of human rights is weak and meritocracy is side-lined. Such problems will be addressed in turn.

\section{Low wages, bribery and extortion in the Afghan justice sector}

In Afghanistan, bribes are paid to attain judicial services and benefits and to avoid delays and further costs. An expert working with civil society organizations claimed that the Afghan public are frustrated with the corrupt Afghan government and corrupt justice and police institutions which are easily bribed. ${ }^{20}$ Any problems addressed with the state should not be confused with the justice sector and vice versa. Low wages debatably enhance bribery if one adopts the low wage hypothesis. In a study on civil servants, Van Rijckeghem and Weder (1997) revealed that low pay is a main cause of corruption; it entices public officials to supplement their salary by extorting bribes while an increase in wages can reduce survival-based corruption.

Afghan judges at the provincial level earn about US-\$50 per month; a court prosecutor is paid an estimated US-\$70 per month and judges within the Supreme Court are paid US-\$80 (Tondini 2007, 337). In an interview, a Legal Researcher of the Max Planck Institute stated that 'judges do not have good salaries; their salary starts from $\$ 50$ dollars so if you are so lowly paid then of course you will do corrupt things'. ${ }^{21}$ Justice providers are susceptible to corruption due to the deficiency of wages to rent an average apartment in Kabul for monthly US-\$150-200. ${ }^{22}$ The 
Chairman of the Afghanistan Human Rights Organization (AHRO) concurred with this argument:

A highly paid Afghan prosecutor or judge earns an estimated monthly salary of 500 Afghanis $\$$ 100. However, normally families spend about 50,000 Afghanis $\$ \$ 1,000$ each per month. If they are taking $\$ 100$ from [the] government, what about the $\$ 900$ other? This is why they are corrupt and this is the reason why...because the government is not able to provide all the facilities to their employees. ${ }^{23}$

This strengthens the notion that judicial corruption is due to poverty and that raising wages can reduce corruption. The Team Leader of ARoLP also stressed that pay reform is greatly needed in order to reduce bribery and extortion within the judiciary at all levels:

There is a pay reform that is now going through but it's going to take about two years to truly implement because they have to reclassify all the positions but somewhere in the mix over the next several years their salaries will be raised significantly and the judges salary will go to 500 or 600 dollars... With pay reform, at least you have hope. ${ }^{24}$

It was not disclosed where the money would come from in order to provide such a steep increase in judges' salaries in Afghanistan. It is important to note that judges' salaries in Afghanistan's neighbouring states are also low. For instance in Tajikistan, judicial staff are paid US-\$30 and not higher than US-\$100 per month (Ezrow and Frantz 2013, 145). Moreover, it is vital to take into consideration that Afghan judges' salaries were raised ten times during the Taliban regime to curb corruption which only resulted in higher bribes (Demirbüken et al. 2009, 139). Therefore, raising wages can also be counterproductive and low pay viewed not as the cause of corruption.

The majority of interviewees claimed that the Afghan justice sector is hindered by bribery and extortion. The Operations Officer of the ARTF argued that justice functions as a market commodity that can be purchased and in the provinces, you pay to get justice so the justice system here is corrupt'. ${ }^{25}$ The Manager for Women's Rights of Action Aid similarly stated that a 'party may be rich and bribe the judge', which determines the outcome of the decision in their favour. ${ }^{26}$ Azami (2009) also argues that adjudicators, the police and civil servants extort bribes from the public to speed-up processes. 62 per cent of Afghan households surveyed by IWA ${ }^{27}$ stressed that they had experienced corruption within the courts as witnesses and complainants (IWA 2010, 11). 
Within the judiciary, corruption mainly occurs at district courts and the Attorney General's Office (AGO) in 39 per cent of cases according to IWA $(2010,11)$. The Team Leader of ARoLP claimed that extortion prevails across the Afghan justice system with higher amounts being paid at higher levels. He specifically argued that the formal judicial sector is expensive due to extortion: a payment of US- $\$ 100$ is made to a judge at the district level, US- $\$ 1,000$ at the provincial level and US-\$10,000 is paid at the Supreme Court. ${ }^{28}$ The Director of IWA argued that the justice sector is perceived as the most corrupt after the police; the most corrupt areas in the justice sector 'include courts and attorneys' concerning land issues as a lot of money is involved in these cases. ${ }^{29}$ The Special Advisor to the Executive Director of the IAM provided a thorough example of a judge who did not travel to Ghazni because there was no guarantee that he would receive a bribe. ${ }^{30}$ The slow process of the justice system and expectation of bribes has impeded the credibility of the justice system. ${ }^{31}$ The Attaché for Justice, Rule of Law and Human Rights of the EU Delegation also argued that 'the formal justice system is extremely slow, very corrupt and hard to understand which just basically means that you have more entry points for corruption' due to delays and susceptibility of bribery. ${ }^{32}$

These perceptions reveal the great dissatisfaction with the justice sector due to delays, bribery and extortion. These shortcomings may be exacerbated by the notion that adjudicators receive low salaries to cover living costs and familial expenses. However, one should also consider that Afghanistan is recovering from over thirty years of war and several regime changes. Hence, one could argue that these perceptions provide exaggerated expectations of the justice sector and contentious causes of corruption such as low pay.

\section{State Capture: Political and Criminal Infiltration of the Afghan Formal Judicial System}

Parts of the Afghan state are infiltrated from criminal networks liaising with political elites to gain from the illicit drug economy. Law enforcement actors, namely police and judges, demand bribes to defer arrests and influence legal proceedings. The Afghan judiciary is also infiltrated from political elites, armed opposition groups and drug traffickers that influence decisions via bribery, harassment, threats and intimidation (Nojumi et al. 2009, 216). ${ }^{33}$ The Advisor of the High Office of Oversight and Anti-Corruption (HOOAC) argued that cronies of the Afghan cabinet and the President corrupt and distort legal investigations, judicial procedures and anticorruption efforts to preserve their power in the form of distributing benefits. ${ }^{34}$ These protective practices are common throughout Afghan institutions due to the political and economic bargaining powers of both the bribe's sources and recipients. Vice versa, such politicized 
institutions also distribute state resources. These interrelationships are central to a political economy approach, including limited access orders, when analysing corruption.

54 per cent of the United Nations Development Programme (UNDP) respondents ${ }^{35}$ suggested that the payment of a bribe can get an individual released prematurely from police custody (UNDP 2009, 20). The Senior Rule of Law Advisor for United States Institute of Peace (USIP) similarly argued that drug smugglers with powerful political connections evade prison as courts function in their interests due to bribery or threats. ${ }^{36}$ The Deputy Chair of the Afghanistan Independent Human Rights Commission (AIHRC) argued that impunity continues 'due to weak judicial organs that fail to prosecute various criminals, warlords and notorious drug traders' ${ }^{37}$ If they are caught, then 'they are released on the same day by police due to a bribe or fear; if not by the police then by the Attorney General, primary court and if not the Supreme Court would release them otherwise the prison will be issued a decree to release these notorious people'. ${ }^{38}$ The Advisor for the HOOAC similarly argued that 'if somebody with power is arrested, the next day he's released on bail and he's never prosecuted or pursued again' and it is the lack of implementing existent laws that is the problem due to connections, the lack of transparency and weak political will. ${ }^{39}$ Therefore, 'the disposition of cases is commonly decided by bribes and those who pay bribes or have influential connections are released' (Chêne 2007, 3). Protection from prosecution can be purchased if the amount is greater than the consequences for refusal. For instance, Chief Judge of the Central Narcotics Tribunal Appeals Court, Mohammad Alim Hanif, refused to take a bribe to rig the outcome of a prosecution and was consequently shot dead on 4 September 2008 by an unidentified gunman. A senior member of a cluster of working NGOs argued that judges need to be protected from such threats to combat judicial corruption. ${ }^{40}$ These perceptions obtained from the interviews suggest that it is the underlying conditions of the state that has resulted to intrusion during criminal and corruption investigations. This clearly fits international explanations of state capture that deems such undesired behaviour as corrupt.

\section{Concept of Corruption within the Afghan Social Context}

As part of the political economy analysis, the nature of political and factional competition is enshrined in informal rules of authority to distribute state resources. In addition, informal rules are based on tribal, ethnic, social and familial ties so that elites can survive and factions can compete. Often, patronage is utilized to attain public resources - goods, political decisions and jobs - that are exchanged between patrons and clients. Administration posts may also be distributed to individuals in exchange for electoral support or other modes of loyalty. Political 
parties are able to unevenly channel state resources to favourable electoral constituencies which include territorial and ethnic groups or certain social classes.

Patronage in Afghanistan was tradition-based which organized both life and governance and was coded in Islamic terms, was hereditary, usually patrilineal and the patron-client relationship was closed to some groups that did not fit the hierarchical structure (Isby 2011). However, Roy (1990, 215-216) argues that the war against the Soviets changed traditional patronage structures in which trail elites extracted resources from the population to one in which new elites Mujahidin commanders - were able to distribute resources (largely aid) to the population in return for support. Traditional patronage, however, is still evident regarding agricultural land.

The Afghan political culture of patronage and clientelism is based on those in powerful positions, such as governors and senior officials, distributing and redistributing state resources. Powerful figures operate as a patron providing appointments and favours based on relationships and political loyalty to establish and preserve patronage networks instead of hiring on principles of meritocracy and equality which overrides proficiency and ethnic balance (Isby 2011).

The US and international allies have not dealt with the pre-existing patronage networks. The former Karzai government was installed and local warlords were paid by the Western intervention for fighting or services. These warlords enjoyed the opium and arms trade that remain as a major source of power and revenue, similar to foreign donor aid sourcing Karzai's power and income. The US supported the 2002 Loya Jirga which backed the political leadership of Karzai with strong hopes that Karzai would bring in the biggest international rents from the Western intervening countries (Kühn 2008, 315). Karzai developed 'a personal patronage network' to survive in Afghan politics by gaining the support of warlords who controlled the countryside by appointing or 'buying them off with offers of cabinet posts and governorships' (Tomsen 2011, 643).

Former President Karzai had no control over both Afghan security institutions. He provided powerbrokers such as Burhanuddin Rabbani and Abdul Rab Rasul Sayyaf the privilege to select cabinet ministers, presidential staff and police chief posts to protect their corruption and narcotics trafficking in exchange of supporting Karzai. The poppy economy can be perceived as a 'form of rent' due to the profit made by exporting refined opium (Kühn 2008, 318). The accumulation of state resources have increased both 'inter-factional competition' and 'costs of appointments' and the sale of posts and protection is also existent in the Presidential Office (Goodhand 2008, 63-64). Karzai appointed his half-brother Ahmad Wali as governor of Kandahar, who became the most powerful warlord of Kandahar and was notorious as a major drug trafficker in Afghanistan. ${ }^{41}$ Despite supported prevalent perceptions, the timing of the 
increased portrayal of Wali may also have been to damage the Karzai name in public so this speculation may not be entirely a true fact. Karzai had cycled warlords ${ }^{42}$ into his cabinet and left them on the voting lists during elections to heighten his own position with anti-Taliban patronclient relationships in decentralized areas. Patronage alliances formed by warlords and other powerful electoral candidates continually dominate Afghan politics as in 2004. Corruption, patronage and nepotism influence senior appointment decisions which affect the quality and access to judicial institutions and public services while the poor suffer the most by paying a higher slice of their incomes (Singh 2014). Goetze and Guzina $(2008,316)$ reveal international assumptions of the failed state paradigm. This is when a state lacks a central authority to enforce law which provides opportunities for warlords and other militias to form networks of fortification and illegal trade. The majority of the interviewees, many quoted in this paper, ${ }^{43}$ concurred with the international assumption of the failed state paradigm in relation to Afghan warlords engaging in poppy trafficking that subvert judicial and anti-corruption processes.

\section{Problems with Appointments, Education and Training in the Afghan Formal Justice System}

The Supreme Court is the highest constitutional court of appeal in Afghanistan and is mandated with the authority of the administration over a judiciary of 1,500 judges. Despite the authority of the Supreme Court, it lacks a transparent system which fails to discipline or dismiss judges for engaging in corruption and is deemed corrupt as an institution alongside the AGO (Jones 2008, 85). The Supreme Court is often manipulated to provide political reviews of the actions undertaken by former President Karzai and blocks parliamentary efforts to overrule presidential vetoes. For instance, Karzai dismissed the Afghan Foreign Minister, Rangin Dadfar Spanta, in May 2007 and used the Supreme Court to vote out Spanta which undermined the independence of the Court.

Judicial appointments have been tainted with political manipulation and bias, particularly from armed opposition groups and warlords, and only 20 per cent of the Supreme Court consists of qualified judges (Stromseth et al. 2006, 233). In the justice system lawyers rarely hold a law degree. ${ }^{44}$ Only 12 per cent of judges hold a law degree, 44 per cent holds an Islamic law degree and only 21 per cent have high school education (Windle and Farrell 2010, 6). In the AGO's ${ }^{45}$ Kabul Office, only 37 per cent of 282 prosecutors held a university degree in 2007 (Tondini 2010, 70). In Uruzgan, none of the seven working judges held a degree (Röder and Zia 2010, 13 14). Rafi (2014) argued that the lack of qualified adjudicators is due to many judges that graduated from an old system or Sharia Law School. These judges arguably lack an understanding of the Afghan Constitution and criminal codes. During an interview, the Team 
Leader of ARoLP stated that 'in some districts, not all judges have graduated from law schools' and 'when you're dealing with judges that haven't even been to law school, there is not a lot of hope'. ${ }^{46}$ This has led to contradicting interpretation of laws and whether decisions are taken in accordance with the Afghan constitution. Moreover, the Executive Director of AIBA stressed that the majority of 'judges and prosecutors don't know about the defence lawyer's responsibility and because of that the defence lawyer is faced with some challenges and problems during cases'. ${ }^{47}$ The understanding of the situation, based on this perception, is based on legal standards and the competency of adjudicators to fulfil such standards.

The flourishing security-induced networks of US support to the Northern Alliance and allowing Karzai to build patronage networks has fostered clientelism and non-adherence with meritocracy. This has resulted in poor screening processes. Moreover, as addressed by the Director of the American Institute of Afghanistan Studies (AIAS), someone with guns and money may pay off a senior official within the Ministry of Interior (MoI) to guarantee a post as Chief of Police and budding governors may engage in a bidding war. ${ }^{48}$ This notion fits international assumptions of the failed state on arbitrary institutions that circumvent meritocracy.

\section{Sociological Approaches: Functionalism and Social Construction}

Corruption may be viewed as part of a predatory neo-patrimonial system for elites to survive by expanding loyalty to political supporters and fellow tribes. Functionalists such as Alatas (1990, 184) deem corruption as a necessary consequence of development. Merton (1968) argues that the covert aspects of political machinery allows political favours to be bought and sold which has economic and political benefits and bribery greases the wheels by enhancing efficiency and undermining red tape. Huntington $(1968,386)$ argues that a bureaucracy with rigid rules can hinder economic growth and it is corruption that helps to integrate people within the political state system. If advocating this functionalist perspective, one could argue that corruption is a necessity for overall economic and political integration.

These arguments underline that corruption improves efficiency. This is based on the notion that widespread and rigid public regulations cost too much economically. These costs can be reduced or even avoided via bribery. The arguments already presented from the interview excerpts, civil society perceptions reports (namely IWA and UNDP) and the literature suggests that bribery and extortion in Afghanistan are part of everyday interactions that may grease the wheels but these processes actually hinder the trust and usage of court systems. Corruption is considered as an evil from Afghan society but the payment of bribes is deemed as an inevitable 
form of interaction with public officials, including judges, who are good officials if they accept payoffs to carry out their duties without delays (Barfield 2012, x). This is referred to as reshwa in Arabic, and means a bribe translated as water obtained from a well with a bucket. Moreover, such transactions may include a gift, favour or tip which is referred to as bakhshish in Afghan courthouses but can also be deemed as reshwa. This is part of a social contract between adjudicators (or public officials) with citizens that utilize such services.

When considering a social construction analysis of corruption, there are many conceptions and manifestations as to what constitutes corruption across the globe. Western conceptions are largely associated with a legalistic view that also includes gift-giving and patronage. In addition, there are similarities and differences in many cultures and contexts, particularly those that have blurred public and private spheres. Gupta's (1995, 379) narration of an Indian land official, Sharmaji, who held an estimated 5,000 plots of land registry at his home but always stated to villagers that it cost money to register or change land titles, illustrates such blurring of public and private spheres. This resulted in villagers not complaining about having to pay bribes or that the office was in the same house with the homeowner performing his duties, as would be argued in a Western setting; instead villagers complained with the performance to attain interaction and deals with state officials. Blurred private and public spheres may be deemed as corruption in the West, while other societies may view it as acceptable behaviour. Thus, corruption is a social construction and specific to cultures and not just states and legal systems (Gupta 1995, 392).

Azfar et al. $(2001,44)$ argue that in some cultures, a gift or tip is provided to a public official for providing a service but it might be debatable as to when a gift or tip constitutes as a bribe. For instance, in China there are social connections and relationships referred to as gaunxi practices where giving gifts forms obligatory mutual cooperation between two familiar parties. Repaying gifts is done on the basis of what feels right and to avoid losing the interest and familiarity because refusal to accept or reciprocate to a gift customarily leads to 'loss of face' (Yang 1989, 42). Similarly in Russia, 'personal networks and informal contacts' to attain services and goods that are scarce and to find ways 'around formal procedures' is called blat. This concerns favours that are based on mutual efficacy - personal ties of kinship or friendship forming moral obligations to help others in which bosses apportion favours to protect their selfimage (Ledeneva 1998, 1). Blat like guanxi focuses on forming and preserving personal and peaceful relationships between the parties involved, forging good, ideally clientelistic and patronage contacts. It can be argued that customary practices in some societies involve giftgiving which is a cultural norm and not deemed as corruption in some states. 
Corruption may be deemed as an endemic or cancer in certain societies and be more focused on moral and ethical impositions. A study conducted by Walton (2012) in Papa New Guinea with 1,825 respondents in nine provinces revealed that corruption is mainly deemed as 'the abuse of public trust for private gain' ( 28 per cent); as all bad and evil acts (26 per cent) and all immoral acts (17 per cent). Perceptions revealed high emphasis on both moral and legal codes. The majority of conceptions regarding what is deemed as corruption emphasized small scale immoral (and potentially illegal) behaviour such as a young woman selling sex as corruption (68 per cent of the respondents expressed this) as most harmful. Bribery and embezzlement were considered as less harmful. Only 60 and 39 per cent of the respondents respectively claimed that bribery and embezzlement was totally corrupt (Walton 2012, 3-7). If corruption is prevalent and deemed as a great evil and/or cancer then it could be argued that moral and social principles can function as a remedy. Approaches that look at morality and ethics are relevant to the society and/or cultures. This can include focusing on religion, ethics and morality with the use of empowering religious leaders, particularly in non-secularized societies.

\section{The Need to focus on Islam, Ethics and Morality}

Islamic principles, law and customs differ from Western-based imposed ideals such as the rule of law. However, the latter has been the primary focus in relation to Afghan centralization of state justice. This shaped the arguments to counter corruption as illicit gain which entered the ANDS (2008) and led to the ratification of the United Nations Convention against Corruption and creation of the HOOAC. If a theological lens is applied, then it can be contended that a rich man may be able to pay for justice but he will be unable to pay in the eyes of God because one cannot purchase a lawyer for such defence. This thinking may be relevant for societies that value religion extensively and rely on religious interpretations of wrongful behaviour, including corruption. However, Pavarala and Malik (2010) indicate that there is no substantive evidence whether religiosity significantly reduces corruption. In Afghanistan, the 2004 Constitution specifies the importance of Islamic jurisprudence over legal norms: rules are to be intertwined with modernized rule of law and human rights standards. This arguably fits a model of legal pluralism. Combining traditional or religious law is only pluralist when there are contradictions. This seems to be the case, and what constitutes pluralism is the willing or tacit acceptance of such different interpretations, to retain both systems in place and injustices remain unresolved.

There is little study on how ethics, morality, and religion in contrast with modernity affect causes and consequences of corruption. Religious leaders may be respected and can act as 
pivotal figures in curbing corruption if provided extensive roles. In Afghanistan, linking religion is very important:

What is needed is for a Mullah to rise and link religion in an Islamic state to promote pride and an ideology for making Afghanistan a better country providing security and justice for its citizens. This will bring about a better competent and less-corrupt police force because since 1995, Mullah Omar radicalized the Taliban via religion and this insurgency fights constantly with little remuneration. In the 1990s, higher law enforcement actors under the Mujahidin were engaged in corruption but the lower were not because they worked for a mandate; to protect people and have national pride for Afghanistan. Now, this has been lost as the police and judges do not have any pride and do not know what they are working for. ${ }^{49}$

The international community has attempted to circulate basic rule of law and human rights standards in informal settings and teachings in schools and seminars conducted by Mullahs (Tondini 2007, 342). Italy with additional donors and the UNDP have led this process since 2002 to spread formal legal standards throughout provinces and districts whilst supporting local councils. One example was provided by DFID's Justice Adviser. This is the multi-financed Access to Justice at District Level to educate formalized modes of justice in rural areas that do not have access to formal legal structures:

In the Upper Gereshk Valley [in Helmand], community councils outreach some of the elders which are programmed through the Ministry of Justice and Human Rights Commission to give some education to senior representative elders, local Jirgas and the Ministry of Justice department. Some community councils had 300 elders turning up, drinking tea and talking about legal rights. These outreach programmes are actively supporting Afghans and will support through Afghans educating the elders. The Human Rights Commission is to train the leading Jirga members so that they can pass messages to their Mullahs. Rights issues are not solved overnight but we need to work on it in a multifaceted approach on all levels in an Afghan context. Afghans are sitting and discussing at the community level. ${ }^{50}$ 
The IWA nationwide survey $(2010,95)$ revealed that 55 per cent of its respondents underlined that Mullah and Ulema are the best institutions to combat corruption. Only 25 per cent claimed that they would not be efficient to do so. The Director of IWA argued that the state is weak and is not trusted and therefore the judges are not 'called upon'; when there is a complaint, informal solutions such as third party elders and Mullahs are consulted nationwide. ${ }^{51}$ The Director further claimed that these respectable and trusted elders and Ulema have a reputation to resolve disputes. ${ }^{52}$ These perceptions reveal that the social contract between citizens and justice providers has weakened. This has undermined faith of the justice system and resulted in the belief that local power-holders are more trustworthy and less susceptible to corruption than state modes of justice. These figures are in a position to be empowered in order to promote human rights and anti-corruption.

\section{Conclusion}

This paper considers several approaches when analysing corruption. A political economy approach to corruption is integral for understanding the role of the institutions, structures and behaviours and political and criminal processes. The main features of Afghanistan's political economy are complex that is concerned not just with informal networks, but institutional ones. The rules of the game concern both rules of a formal and informal nature, cultural norms and neo-patrimonial ties whether ethnic, tribal, familial or social, which governs actors' behaviours. Predation, rent-seeking and patronage are behaviours endorsed by elites to preserve loyalty, power and manipulation of the distribution of state resources and appointments without compliance of meritocracy. In addition, the main behaviours of lowly paid judges and prosecutors consist of extorting bribes as an economic coping strategy. These practices resemble the close connection between political and economic power and rent seeking as theorized by North et al. (2013) limited access orders. ${ }^{53}$

Such political processes do not only benefit the ruling elite but also criminal networks engaged in the drug industry that have captured parts of the state. This has hindered the actions of law enforcement officials by bribery, intimidation and threats. These private actors lobby with elites, profiting from the redistribution of public funding and controlling or running illicit black markets contingent on immunity from prosecution. ${ }^{54}$ Senior officials and Afghan parliamentarians engaged in drug trafficking and previous human rights violations were pardoned according to the Amnesty Blanket Immunity Law. As a matter of policy, this law should be repealed if the rule of law is to be strengthened. Therefore, the causes and 
consequences of corruption that are based on the structures, institutions and political and criminal processes highlighted by a political economy approach illustrate the mutual influences of practices and the justice sector.

A legal pluralist approach has focused on the rule of law and a dirigiste approach to statebuilding. Judicial reform efforts from Italy and additional donors have attempted to copy and link formalized legal rules and standards - including human rights, Shari'a Law and the Afghan Constitution - to the countryside. A legal pluralist approach includes providing certain powers to local respected figures which would develop accountability from the bottom-up process within local councils. Despite such efforts and contention, based on the researchers' fieldwork, the main argument presented is that the Supreme Court, and Afghan government to an extent, does not want extrajudicial systems of community-dispute resolution processes to gain legal recognition to avoid being held accountable for corruption probes. Most crucial, even if legal pluralism was to function in Afghanistan, this would take a generation or two as the main issues are not solely down to prevalent corruption but the case tracking systems in the countryside are very weak or virtually non-existent. Moreover, there are intrinsic contradictions in the legal codes which would take generations to rectify. Decisions held on land issues, family disputes and minor forms of crime by nominated elders need documenting so that such decisionmaking, whether legally justified or not, strive towards consistent standards so that legal pluralism can succeed if such an approach is pursued.

Justice is perceived as a market commodity which would fit a functionalist model of analysis in order to grease the wheels of a bureaucratic machinery. This has, however, weakened the social contract between people and the justice sector and thus undermined faith and legitimacy of the justice system. There is also a social contract between people and other non-state actors such as elders or other trusted parties who chief community-based dispute resolution processes. Hence, citizens are reluctant to utilize the legal system and judicial services due to prevalent corruption, namely bribery, with higher rates paid at higher courts. According to the majority of the interviewees, there is a dichotomy of the formal and informal modes of justice in Afghanistan and the informal modes are consulted despite renowned human rights abuses due to prevalent corruption in the formal sector.

An increase in wages for judicial staff has been proposed by many of the interviewees as a strategy to reduce corruption but this may also increase the demand for higher paid bribes. It can also be contended that the manifestations and perceptions of corruption differ from one society to the next. Gift-giving and other informal practices are part of a social contract to maintain relations that may be deemed as corruption in the West but not in Asian and African societies. In 
addition, other cultures may deem immoral acts such as selling sex or a fasad as higher forms of corruption over bribery and embezzlement, as addressed by Walton's (2012) study in Papa New Guinea and De Lauri's (2013) study on the Afghan justice sector. These may differ from Western definitions. The essence of such an analysis and approach teaches us that corruption is socially constructed dependent on the perceptions rather than textbook definitions.

Given the empirical nature of this paper, the perceptions of corruption in Afghanistan - based on the interviews conducted in mainly Kabul - can be associated with the common narratives that can be accessed in policy papers and agency reports. The low pay explanation of enticing petty forms of corruption, the lack of case tracking systems and adjudicators' poor understanding of human rights and legal standards - and many other factors as addressed in this paper - were frequently emphasized by the interviewees. These manifestations of the causes and consequences of judicial corruption and alleged ignorance of human rights standards, namely in the countryside, are unitedly shared by those interviewed in Kabul.

In addition, traits of the international failed state paradigm were stressed by many of the interviewees. They stressed that patronage, nepotism and opportunities for warlords and criminal networks to profit from opium trafficking persisted. It was expressed that these features undermined the rule of law, judicial processes and corruption investigations. It may be questioned whether these limited variations in explaining corruption, and other problems addressed, imply that the very narrative that the majority of Afghan adjudicators and parliamentarians are corrupt shapes international perceptions of all undesired behaviour as corrupt. It can also be contended that the justice sector is particularly prone to accusations of corruption in many parts of the world, especially by those who do not get the desired results. Hence, the manifestations of the shortcomings of the Afghan justice sector as expressed by the interviewees are based on internationally framed understandings of corruption, legal standards, human rights, capacity frailties and the failed state syndrome that arguably led to Taliban remobilization. Despite such contentions, this paper has analytically distinguished where the problems arise from corruption that includes legal pluralism and the lack of funding but also of exaggerated expectations towards the state and the justice sector.

In terms of dialogue and training, Islam, morality and ethics that are relevant to the Afghan context can form stronger debates and enhance efforts for Afghans to discuss corruption and develop measures to curb it. Instead of forming a dichotomy between formal and informal justice in Afghanistan and the pitfalls of both - notably bribery and human rights abuses respectively legal pluralism can only merge all forms of jurisprudence by including influential figures such as Mullahs to place higher emphasis on the rule of law, various legal codes and human rights. 
Therefore, the sociological and political economy approaches to corruption and emphasis on morality, ethics and religion help identifying problems in the Afghan judicial sector and methods to curb corruption. Such an approach is pivotal to conjure a viable anti-corruption strategy - and legal pluralist approach if pursued - as the new President, Ashraf Ghani Ahmadzai, has a huge task to restore public faith in the highly corrupt, inaccessible and incompetent justice sector. With recent decreased international involvement, the justice sector needs to have a high priority in order to avoid further Taliban resurgence.

\section{Acknowledgements}

The author would like to thank all of the interviewees for participating in this study, which made this research conducted in Afghanistan possible. In addition, thanks to the editors and both anonymous peer reviewers for suggestions to improve this paper.

\section{Notes}

${ }^{1}$ Jirga is the term used by many Pashtuns, while the synonymous term Shura is used by Darispeakers.

${ }^{2}$ Author interview, DFID Justice Adviser: UK Aid, Kabul, 6 June 2010.

${ }^{3}$ Author interview, Director of IWA, Kabul, 3 June 2010.

${ }^{4}$ According to Tondini $(2007,335)$, at least 80 per cent of Afghans are illiterate.

${ }^{5}$ See n.2.

${ }^{6}$ Author interview, Team Leader of ARoLP, Kabul, 3 June 2010.

${ }^{7}$ See n.2.

${ }^{8}$ Author interview, Operations Officer of ARTF: The World Bank Group, 5 June 2010.

${ }^{9}$ Author interview, Peacebuilding and Public Relations Manager of ACSFo, Kabul, 1 June 2012.

10 Author interview, Deputy Country Coordinator and Legal Researcher of the Max Planck Institute for Comparative Public Law and International Law, Kabul, 27 May 2012.

${ }^{11}$ Author interview, Executive Director of AIBA, Kabul, 1 June 2012.

12 Author interview, Program Director for Law, Human Rights and Women's Empowerment of The Asia Foundation, Kabul, 26 May 2012.

${ }^{13}$ See n.3.

${ }^{14}$ Author interview, Special Advisor to the Executive Director of IAM, Kabul, 31 May 2012.

${ }^{15}$ See n.3.

${ }^{16}$ See n.6.

${ }^{17}$ Author interview, Country Director of Global Rights: Partners for Justice, Kabul, 3 June 2012.

${ }^{18}$ Two of numerous clear international corruption probes against Karzai's family include Ahmad Wali and Mahmoud Karzai for illicit drug trafficking and businesses, tax evasion and racketeering respectively.

${ }^{19}$ Scholars who write about the political economy of corruption, such as Rose-Ackerman (1997, 33 ), suggest that corruption usually distorts 'the allocation of economic benefits, favouring the 
haves over the have-nots and leading to a less equitable income distribution' and often public and private spheres are not differentiated.

${ }^{20}$ See n.9.

${ }^{21}$ See n.10.

${ }^{22}$ Author interview, Justice Sector Support Programme Legal Consultant of the AGO, Kabul, 29 May 2012. The Finance Director and interim Director of the Institute for War and Peace Reporting also argued that judges were lowly paid which exacerbates the demand of bribes from people (author interview, Kabul, 31 May 2012).

${ }^{23}$ Author interview, Chairman of AHRO, Kabul, 31 May 2012.

${ }^{24}$ See n.6.

${ }^{25}$ See n.8.

${ }^{26}$ Author interview, Manager for Women's Rights of Action Aid, Kabul, 26 May 2012.

${ }^{27}$ IWA conducted the first truly national survey that covers the perceptions of 6,500 respondents across 32 Afghan provinces out of a possible 34 in December 2009.

${ }^{28}$ See n.6.

${ }^{29}$ See n.3.

${ }^{30}$ See n.14.

${ }^{31}$ See n.8.

${ }^{32}$ Author interview, Attaché for Justice, Rule of Law and Human Rights of the EU Delegation, Kabul, 6 June 2012.

33 This fits the explanations of a political economy approach as illustrated by Rose-Ackerman. She argues that private groups such as drug lords bribe, threaten or intimidate these actors in exchange of retaining immunity from prosecution and to also monopolize their authority in the black market (Rose-Ackerman 1996, 2-3).

${ }^{34}$ Author interview, Advisor of the HOOAC, Kabul, 4 June 2012.

${ }^{35}$ UNDP's survey consists of a nationwide report of 5,156 persons aged 18 years or over across all 34 Afghan provinces over 12 days.

${ }^{36}$ Author interview, Senior Rule of Law Advisor for USIP, Kabul, 30 May 2010.

${ }^{37}$ Author interview, Deputy Chair of AIHRC, Kabul, 27 May 2012.

${ }^{38}$ See n.37.

${ }^{39}$ See n.34.

40 Author interview, Deputy Director of the Agency Coordinating Body for Afghan Relief, Kabul, 31 May 2010.

${ }^{41}$ Author interview, Access to Justice Manager of The Asia Foundation, Kabul, 26 May 2012.

42 According to Lezhnev (2005, 5-7), warlords are motivated by personal power, wealth and financial resources and prestige primarily but resources are the symptom of the quest for power.

${ }^{43}$ Author interviews, Deputy Chair of AIHRC (see n.37); Senior Rule of Law Advisor for USIP (see n.35).

${ }^{44}$ See n. 17.

45 The AGO has authority for investigating crimes which includes an estimated 2,500 public prosecutors.

${ }^{46}$ See n.6.

${ }^{47}$ See n.11.

${ }^{48}$ Author interview, Director of AIAS, Kabul, 26 May 2012.

${ }^{49}$ Author conversation, Chairman of the PRDU, York, 3 February 2012.

${ }^{50}$ See n.2.

${ }^{51}$ See n.3.

${ }^{52}$ See n.3. 
${ }^{53}$ Such practices are rife in Afghanistan and engrained within main institutions such as the MoI as one example that also functions as a shop selling posts to the highest bidders.

${ }^{54}$ This is a consequence of state capture. The Advisor of the HOOAC claimed that in his experience political interference influences judicial and anti-corruption cases and many are dropped due to cronyism (see n.34).

\section{References}

Afghanistan National Development Strategy, 2008. Afghanistan National Development Strategy 1387 - 1391 (2008 - 2013): A Strategy for Security, Governance, Economic Growth and Poverty Reduction. Kabul: Islamic Republic of Afghanistan.

Alatas, S.H., 1990. Corruption: Its Nature, Causes and Functions. Aldershot: Avebury. Azami, S., 2009. "The Need for Security Sector Reform in Afghanistan to Curb Corruption."

Peace \& Conflict Monitor, 4 November 2009. Accessed 16 December 2010. http://www.monitor.upeace.org/innerpg.cfm?id_article=666

Azfar, O., Young, L. and Swamy, A., 2001. "The Causes and Consequences of Corruption." Annals of the American Academy of Political and Social Science 573: 42-56.

Barfield, T., 2012. Afghan Customary Law and Its Relationship to Formal Judicial Institutions. Washington, DC: USIP.

Bliesmann de Guevara, B. and Kühn, F.P., 2013. "The Political Economy of Statebuilding:

Rents, Taxes, and Perpetual Dependency.” In: D. Chandler and T.D. Sisk, eds., The Routledge Handbook of International Statebuilding. London: Routledge, 219-230.

Boucher, A.A., Durch, W.J., Midyette, M., Rose, S. and Terry, J., 2007. Mapping and Fighting Corruption in War-torn States. Washington, DC: Stimson Centre, Report 61.

Centre for Media Studies, 2005. India Corruption Study 2005: To Improve Governance.

Delhi: Transparency International.

Centre for Policy and Human Development, 2007. Human Development Report 2007 -

Bridging Modernity and Tradition: Rule of Law and the Search for Justice. Islamabad: Army Press.

Chêne, M., 2007. Tackling Judicial Corruption in Afghanistan. Berlin: Transparency International.

Chêne, M., 2009. Low Salaries, the Culture of Per Diems and Corruption. Berlin: Transparency International.

Coburn, N. and Dempsey, J., 2010. Informal Dispute Resolution in Afghanistan. United States Institute of Peace (Special Report 247), August. Washington DC: USIP. 
De Lauri, A., 2013. "Corruption, Legal Modernization and Judicial Practice in Afghanistan." Asian Studies Review 37 (4): 527-545.

Demirbüken, H., Mili, H. and Townsend, J., 2009. Addiction, Crime and Insurgency: The Transnational Threat of Afghan Opium, October. Vienna: UNODC.

Fearon, K., 2010. Proximity, Pragmatism and Pashtunwali: Informal Justice at District Level in Helmand, June. Kabul: United Kingdom Foreign and Commonwealth Office: Department for International Development - Stabilization Unit.

Goodhand, J., 2008. "Poppy, Politics, and State Building." In: G. Hayes and M. Sedra, eds. Afghanistan: Transition Under Threat. Waterloo, ON: Wilfrid Laurier University Press, 5186.

Gupta, A., 1995. "Blurred Boundaries: The Discourse of Corruption, the Culture of Politics, and the Imagined State." American Ethnologist 22 (2): 375-402.

Huntington, S.P., 1968. Political Order in Changing Societies. New Haven, CT: Yale University Press.

Integrity Watch Afghanistan, 2010. Afghan Perceptions and Experiences of Corruption: A National Survey. Kabul: Integrity Watch Afghanistan.

Isby, D.C., 2011. Afghanistan - Graveyard of Empires: A New History of the Borderland. New York: Pegasus Books.

Goetze, C. and Guzina, D., 2008. "Peacebuilding, Statebuilding, Nationbuilding - Turtles All the Way Down?" Civil Wars 10 (4): 319-347.

Jones, S.G., 2008. Counterinsurgency in Afghanistan. Santa Monica, CA: RAND Corporation.

Krueger, A.O., 1974. "The Political Economy of the Rent-Seeking Society." The American Economic Review 64 (3): 291-303.

Kühn, F.P., 2008. "Aid, Opium, and the State of Rents in Afghanistan: Competition, Cooperation, or Cohabitation?” Journal of Intervention and Statebbuilding 2 (3): 309-327.

Lambsdorff, J.G., 2002. “Corruption and Rent-seeking.” Public Choice 113: 97-125.

Ledeneva, A.V., 1998. Russia's Economy of Favours: Blat, Networking and Informal Exchange. Cambridge: Cambridge University Press.

Lezhnov, S., 2005. Creating Peace: Strategies to Deal with Warlords in Collapsing States. Plymouth: Lexington Books.

Merton, R.K., 1968. Social Theory and Social Structure. New York: Free Press.

Nojumi, N., Mazurana, D. and Stites, E., 2009. After the Taliban: Life and Security in Rural Afghanistan. Lanham, MD: Rowman and Littlefield Publishers, Incorporated. 
North, D.C., Wallis, J.J., Webb, S.B. and Weingast, B.R., 2013. In the Shadow of Violence: Politics, Economics, and the Problems of Development. Cambridge: Cambridge University Press.

Nye, J.S., 1967. "Corruption and Political Development: A Cost-Benefit Analysis.” American Political Science Review 61 (2): 417-427.

Pavarala, V. and Malik, K.K., 2010. "Religions, Ethics and Attitudes towards Corruption: A Study of Perspectives in India." Religions and Development Working Paper 53, Birmingham: UK Aid/University of Birmingham International Development Department. Philp, M., 2008. "Peacebuilding and Corruption.” International Peacekeeping 15 (3): 310-327. Pimentel, D., 2011. "Legal Pluralism in Post-Colonial Africa: Linking Statutory and Customary Adjudication in Mozambique.” Yale Human Rights and Development Journal 14 (1): 59-104.

Rafi, S., 2014 “Judging Women's Access to Justice - An Insider's View.” British and Irish Agencies Afghanistan Group, 29 September [online]. Accessed: http://www.baag.org.uk/views-voices/judging-womens-access-justice-insiders-view (7 March 2015).

Rimsky, V., 2005. "Bureaucracy, Clientage and Corruption in Russia." Social Sciences 36 (2): $32-44$.

Röder, T. and Zia, S.H., 2010. Provincial Needs Assessment: Criminal Justice in Uruzgan Province. Berlin: German Technical Corporation.

Rose-Ackerman, S., 1996. The Political Economy of Corruption - Causes and Consequences. World Bank: Private Sector Development Department (Note No. 74), April. Washington, DC: World Bank.

Rose-Ackerman, S., 1997. "The Political Economy of Corruption". In: K.A. Elliott (ed.) Corruption and the Global Economy. Washington: Institute for International Economics, 3160.

Rose-Ackerman, S., 1999. Corruption and Government: Causes, Consequences, and Reform. Cambridge: Cambridge University Press.

Roy, O., 1990. Islam and Resistance in Afghanistan, 2nd edn. Cambridge: Cambridge University Press.

Sedra, M., 2006. "Security Sector Reform in Afghanistan: The Slide towards Expediency." International Peacekeeping 13 (1): 94-110.

Singh, D., 2014. "Corruption and Clientelism in the Lower Levels of the Afghan Police." Conflict, Security \& Development 14 (5): 621-650. 
Stromseth, J., Wippman, D. and Brooks, R. 2006. Can Might Make Rights? Building the Rule of Law after Military Interventions. Cambridge: Cambridge University Press.

Tomsen, P., 2011. The Wars of Afghanistan: Messianic Terrorism, Tribal Conflicts, and the Failures of Great Powers. New York: PublicAffairs/Perseus Books.

Tondini, M., 2007. "Rebuilding the System of Justice in Afghanistan: A Preliminary Assessment." Journal of Intervention and Statebuilding 1 (3): 333-354.

Tondini, M., 2010. Statebuilding and Justice Reform: Post-Conflict Reconstruction in Afghanistan. London: Routledge.

United Nations Development Programme, 2009. Police Perception Survey 2009: The Afghan Perspective. Kabul: United Nations Development Programme.

Van Rijckeghem, C. and Weder, B., 1997. Corruption and the Rate of Temptation: Do Low Wages in the Civil Service Cause Corruption? 1 June 1997. IMF Working Paper WP/97/73. Washington, DC: International Monetary Fund.

Waldman, M., 2008. Falling Short: Aid Effectiveness in Afghanistan. Kabul: Oxfam International.

Walton, G., 2012. Papa New Guinean Interpretations of Corruption: Insights from a Nine Province Survey. Melbourne, VC: Australian National University/University of Melbourne.

Wardak, A., 2004. "Building a Post-war Justice System in Afghanistan.” Crime, Law and Social Change 41: 319-341.

Wardak, A., 2005. "Building a Post-War Justice System in Afghanistan.” In: N. Yassari, ed. The Shari' $a$ and the Constitutions of Afghanistan, Iran and Egypt - Implications for Private Law. Tübingen: Mohr Siebeck, 61-82.

Wimpelmann, T., 2013. "Nexuses of Knowledge and Power in Afghanistan: The Rise and Fall of the Informal Justice Assemblage." Central Asian Survey 32 (3): 406-422.

Windle, J. and Farrell, G., 2010. “Afghanistan.” In: J.P. Stamatel and H.-en. Sung, eds. Crime and Punishment: Around the World. Santa Barbara, CA: ABC-CLIO, LLC, 1-12.

World Bank, 2005. Afghanistan: Managing Public Finances for Development, Improving Public Financial Management in the Security Sector. Washington, DC: World Bank.

Yang, M.M.-S., 1989. "The Gift Economy and State Power in China." Society for Comparative Study of Society and History 31 (1): 25-54. 